\title{
UPAYA MENINGKATKAN KEMAMPUAN MOTORIK HALUS MELALUI BERMAIN PLASTISIN
}

\author{
Siti Khabibatur Rohmah ${ }^{1}$, I Ketut Gading ${ }^{2}$ \\ ${ }^{1}$ Jurusan Pendidikan Guru Pendidikan Anak Usia Dini, ${ }^{2} J u r u s a n$ Bimbingan Konseling, Fakultas IImu \\ Pendidikan, Universitas Pendidikan Ganesha , Singaraja, Indonesia \\ e-mail: khabibaturs@gmail.com ${ }^{1}$, ketutgading35@gmail.com²
}

\begin{abstract}
Abstrak
Penelitian ini bertujuan untuk mengetahui peningkatan kemampuan motorik halus anak melalui bermain plastisin. Jenis penelitian ini adalah penelitian tindakan kelas (PTK) yang dilaksanakan dalam dua siklus. Subjek penelitian adalah 18 orang anak. kelompok $A_{2}$ Semester I di TK Laboratorium Undiksha Singaraja Tahun Ajaran 2018/2019. Pengumpulan data dalam penelitian ini dilakukan dengan metode observasi dengan instrumen lembar observasi. Data hasil penelitian yang diperoleh dianalisis dengan menggunakan teknik analisis statistik deskriptif. Hasil penelitian menunjukkan bahwa terjadi peningkatan kemampuan motorik halus melalui bermain plastisin. Pada siklus I capaian kemampuan motorik halus sebesar $57.62 \%$, sehingga menunjukkan pada kategori rendah kemudian mengalami peningkatan pada siklus II menjadi $81.56 \%$ pada kategori tinggi.
\end{abstract}

Kata kunci: Bermain plastisin, Kemampuan Motorik Halus

\begin{abstract}
This study aims to determine the improvement of children's fine motor skills through playing plasticine. This type of research is classroom action research (CAR) which is carried out in two cycles. The research subjects were 18 children in group $A_{2}$ Semester I in Undiksha Singaraja Laboratory Kindergarten 2018/2019 Academic year. Data collection in this study was carried out by out by observation method with observation sheet instrument. The research data obtained were analyzed using descriptive statistical analysis techniques. The results showed that there was an increase in fine motor skills through playing plasticine. In the first cycle the achievement of fine motor skills was $57.62 \%$, so it showed in the low category then it increased in the second cycle to $81.56 \%$ in the high category.
\end{abstract}

Keywords : Play Plasticine, Fine Motor Skills 


\section{PENDAHULUAN}

Anak usia dini adalah sosok individu yang sedang menjalani proses perkembangan dengan pesat dan fundamental bagi kehidupan selanjutnya. Anak usia dini memegang peranan yang sangat penting karena perkembangan otak manusia mengalami lompatan dan berkembang sangat pesat, yaitu mencapai $80 \%$. Ketika dilahirkan ke dunia, anak manusia telah mencapai perkembangan otak $25 \%$, sampai usia 4 tahun perkembagannya mencapai $50 \%$, dan sampai 8 tahun mencapai $80 \%$, selebihnya berkembang sampai usia 18 tahun.

Berdasarkan Undang-Undang Nomor 20 Tahun 2003 tentang Sistem Pendidikan Nasional pasal 1 angka 14 menyatakan bahwa Pendidikan Anak Usia Dini (PAUD) adalah suatu upaya pembinaan yang ditujukan kepada anak-anak sejak lahir sampai dengan usia enam tahun yang dilakukan melalui pemberian rangsangan pendidikan untuk membantu pertumbuhan dan perkembangan jasmani dan rohani agar anak memiliki kesiapan dalam memasuki pendidikan lebih lanjut (Kemendiknas, 2009:1).

Taman Kanak-kanak adalah salah satu bentuk satuan pendidikan anak usia empat sampai enam tahun untuk menciptakan situasi pendidikan yang dapat memberikan rasa aman dan menyenangkan bagi anak. Masa ini pula yang merupakan masa untuk meletakkan dasar pertama dalam mengembangkan kemampuan fisik motorik, kognitif, bahasa, sosial emosional, konsep diri, disiplin, kemandirian, seni, moral dan nilai-nilai agama supaya pertumbuhan dan perkembangan anak tercapai secara optimal (Permendikbud No 137 Tahun 2014).

Menurut Septiari (2012: 15) kemampuan motorik halus adalah kemampuan yang berhubungan dengan keterampilan fisik yang melibatkan otototot kecil, koordinasi mata dan tangan.

Oleh karena itu gerakan ini tidak teralu membutuhkan tenaga, namun gerakan ini membutuhkan koordinasi mata dan tangan yang cermat. Biasanya gerakan motorik halus biasanya dilakukan seperti, mengancing baju, menggunting, menulis, mewarnai, dan gerakan-gerakan tangan yang lain

Perkembangan gerak motorik halus merupakan meningkatnya pengkoordinasian gerak tubuh yang melibatkan otot dan saraf yang jauh lebih kecil atau detail. Kelompok otot dan saraf inilah yang nantinya mampu mengembangkan gerak motorik halus seperti meremas kertas, menyobek, menggambar, menempel, menjahit dan sebagainya.

Namun tidak semua anak mengalami perkembangan motorik yang sempurna, sesuai dengan perkembangan usianya, ada banyak hal yang menjadi masalah dalam perkembangan motorik seorang anak terutama motorik halusnya. Perkembangan motorik halus yang baik akan mempengaruhi perkembangan yang lainnya seperti perkembangan koordinasi mata dan tangan.

Namun setelah diamati di Taman Kanak-kanak Laboratorium Undiksha Kelompok $A_{2}$ tahun pelajaran 2018/2019 yang berusia 4-5 tahun dalam perkembangan motorik halusnya terlihat kurang maksimal. Anak belum bisa bermain .

Hurlock dalam Suyadi (2009: 178) mengungkapkan perkembangan gerak motorik halus merupakan meningkatnya koordinasi gerak tubuh yang melibatkan otot dan saraf yang jauh lebih kecil atau detail. Kelompok otot dan saraf inilah yang nantinya mampu mengembangkan gerak motorik halus seperti meremas kertas, merobek, menggambar, menulis, dan lain sebagainya.

Hambatan yang terlihat pada perkembangan motorik halus anak pada Taman Kanakkanak Laboratorium Undiksha kelompok A1 dapat diperkirakan beberapa hal seperti: rendahnya kemampuan motorik halus anak melalui bermain plastisin, karena kurangnya sarana dan prasarana dalam kegiatan pembelajaran guru yang kurang bervariasi.

Menurut Dewey (dalam Montolalu, 2009: 1.7) anak belajar tentang dirinya sendiri serta dunianya melalui bermain. Melalui pengalaman-pengalaman awal bermain yang bermakna menggunakan benda-benda konkret, anak mengembangkan kemampuan dan pengertian dalam memecahkan masalah sedangkan perkembangan sosialnya meningkat melalui interaksi dengan teman sebaya dalam bermain. 
Untuk mengembangkan kemampuan motorik halusnya, guru juga harus menggunakan suatu permainan yang bisa mendukung kemampuan motorik halus anak. Salah satunya bermain plastisin adalah yang cocok untuk meningatkan kemampuan motorik halus. Karena seperti yang diungkapkan oleh Parten (dalam Dockett dan Fleer, 2000: 14) memandang kegiatan bermain sebagai sarana sosialisasi, diharapkan melalui bermain dapat memberi kesempatan anak bereksplorasi, menemukan, mengekspresikan perasaan, berkreasi, dan belajar secara menyenangkan. Selain itu, kegiatan bermain dapat membantu anak mengenal tentang diri sendiri, dengan siapa anak hidup serta lingkungan tempat dimana anak hidup.

Swartz (2005: p.59) mengatakan bahwa plastisin merupakan bahan yang digunakan untuk bermain oleh anak-anak di kelas. Plastisin memberikan pengalaman yang menyenangkan dan memuaskan bagi anak-anak, namun bukan hanya aktivitas "bersenangsenang". Sedangkan menurut Well Mina dalam Rochayah (2012: 20), "Plastisin/lilin malam juga termasuk clay (tanah liat), biasanya untuk mainan anak banyak dijual di toko dengan banyak warna dan mudah dibentuk".

Berdasarkan pendapat diatas sehingga dapat disimpulkan bahwa plastisin adalah adonan atau benda lunak dengan berbagai warna yang dapat dibuat menjadi bentuk yang lain dengan cara ditekan-tekan, diremas-remas, dibentuk, dicetak sesuai dengan keinginan dan imajinasi anak, sehingga dengan bermain plastisin dapat mengembangkan semua aspek perkembangan anak. Bermain plastisin memberikan kesenangan dan kepuasan pada anak-anak.

Bermain plastisin memberikan banyak tujuan untuk meningkatkan motorik halus anak, diantaranya yaitu agar pembelajaran bisa lebih efektif, dengan lingkungan yang sudah dikenal anak maka anak dapat menerima dan menguasai dengan baik. agar pelajaran jadi relefan dengan kebutuhan siswa sesuai dengan minat dan perkembangannya.agar lebih efisien murah dan terjangkau yakni dengan menggunakan bahan alam, seperti tanah liat. Karena pembelajaran yang disukai anak adalah melalui bermain maka metode bermain plastisin sangat tepat untuk langkah awal pembentukan kreativitas karena diawali dengan proses melemaskan plastisin dengan meremas, merasakan, menggulung, memipihkan, dll

Pada dasarnya anak usia dini memiliki potensi kemampuan motorik, namun setiap anak memiliki kemampuan yang berbeda-beda, seperti halnya pada anak kelompok $A_{2}$ di TK Laboratorium Undiksha Singaraja. Berdasarkan hasil observasi Di TK Laboratorium Undiksha Singaraja pada anak kelompok $\mathrm{A}_{2}$ ditemukan permasalahan pada kemampuan motorik halusnya. Dapat dilihat pada pembelajaran yang berlangsung, permasalahan sebagaian besar anak adalah ketika anak diajak membuat bentuk menggunakan media plastisin anak-anak masih sering bingung dan belum bisa memahami instruksi atau perintah guru selain itu, belum mampu memegang pensil dengan benar, beberapa anak belum mampu menggunting kertas secara sederhana, anak belum mampu menyobek kertas dan menempelnya secara sederhana ini dikarenakan tangan anak masih kaku dan kurang lentur.

Berdasarkan permasalahan yang telah dikemukakan di atas, maka fokus penelitian ini adalah upaya untuk mengetahui sejauh mana penerapan bermain plastisin untuk meningkatkan perkembangan motorik halus anak, khususnya di Taman Kanak-kanak. Oleh karena itu, fokus dalam penelitian ini adalah mengetahui penerapan bermain plastisin untuk meningkatkan perkembangan motorik halus pada anak kelompok $A_{2}$ TK Laboratorium Undiksha Singaraja tahun pelajaran 2018/2019.

\section{METODE}

Penelitian ini merupakan penelitian Tindakan Kelas atau Classroom Action Ersearch. Penelitian Tindakan Kelas merupakan suatu bentuk penelitian yang bersifat reflektif dengan melakukan tindakan-tindakan tertentu agar dapat memperbaiki dan atau meningkatkan praktek-praktek pembelajaran di kelas secara lebih professional (Agung, 2010:3). 
Penelitian Tindakan Kelas memiliki peranan yang sangat penting untuk meningkatkan mutu pembelajaran melalui suatu tindakan bermakna dengan menggunakan strategi, model, metode atau suatu pendekatan pembelajaran yang diperhitungkan dapat memecahkan masalah atau memperbaiki situasi dan kemudian secara cermat mengamati pelaksanaannya untuk mengukur tingkat keberhasilannya

Pada Penelitian Tindakan Kelas ini peneliti memfokuskan penelitian pada upaya meningkatkan motorik halus melalui bermain plastisin pada kelompok $\mathrm{A}_{2}$ di TK Laboratorium Undiksha Singaraja. Tujuannya adalah untuk mengetahui seberapa besar kemampuan motorik halus anak dalam kegiatan bermain plastisin.

Adapun alasan lain memilih PTK sebagai model penelitian yaitu selain obyek penelitian di kelas, melalui PTK mampu meningkatkan kompetensi guru dalam mengatasi masalah pembelajaran yang menjadi tugas utamanya, memperbaiki atau meningkatkan kinerja belajar dan kompetensi anak serta memperbaiki dan meningkatakan kualitas proses pembelajaran di kelas.

Penelitian Tindakan Kelas memiliki peranan yang sangat penting untuk meningkatkan mutu pembelajaran melalui suatu tindakan bermakna dengan menggunakan strategi, model, metode atau suatu pendekatan pembelajaran yang diperhitungkan dapat memecahkan masalah atau memperbaiki situasi dan kemudian secara cermat mengamati pelaksanaannya untuk mengukur tingkat keberhasilannya

Pada Penelitian Tindakan Kelas ini peneliti memfokuskan penelitian pada upaya meningkatkan motorik halus dalam kegiatan bermain plastisin kelompok $A_{2}$ di TK Laboratorium Undiksha Singaraja. Tujuannya adalah untuk mengetahui seberapa besar kemampuan motorik anak melalu kegiatan bermain plastisinSubjek dalam penelitian ini adalah anak-anak Kelompok $A_{2}$ TK Laboratorium Undiksha Singaraja Tahun Pelajaran 2018/2019. Anak Kelompok $A_{2}$ ini berjumlah 18 orang terdiri dari 9 anak laki-laki dan 9 anak perempuan. Objek yang ditangani dalam penelitian ini adalah kemampuan motorik halus anak kelompok $\mathrm{A}_{2}$ di TK Laboratorium Undiksha Singaraja, semester I Tahun Ajaran 2018/2019.

Penelitian tindakan kelas dilakukan secara tersiklus. Masing-masing siklus terdiri dari empat tahapan yaitu perencanaan tindakan, pelaksanaan tindakan, observasi/ evaluasi dan refleksi.

Pada tahap perencanaan terdiri kegiatan sebagai berikut. (1) Mengidentifikasi dan menganalisis masalah, yaitu secara jelas dapat dimengerti masalah apa yang akan diteliti. Masalah tersebut harus benar-benar faktual terjadi di lapangan, masalah bersifat umum di kelasnya, masalahnya cukup penting dan bermanfaat bagi peningkatan mutu hasil pembelajaran, dan masalah pun harus dalam jangkauan kemampuan peneliti. (2) Menetapkan alasan mengapa penelitian tersebut dilakukan, yang akan melatarbelakangi PTK (3) Merumuskan masalah secara jelas, baik dengan kalimat tanya maupun kalimat pertanyaan. (4) Menetapkan cara yang akan dilakukan untuk menemukan jawaban, berupa rumusan hipotesis tindakan. Umumnya dimulai dengan menetapkan berbagai alternatif tindakan pemecahan masalah, kemudian dipilih tindakan yang paling menjanjikan hasil terbaik dan yang dapat dilakukan guru. (5) Menentukan cara untuk menguji hipotesis tindakan dengan menjabarkan indikator-indikator keberhasilan serta berbagai instrumen pengumpul data yang dapat dipakai untuk menganalisis indikator keberhasilan itu.

Upaya yang dilakukan oleh guru/ peneliti untuk melakukan perbaikan atau peningkatan yang diinginkan. Kegiatan yang dilakukan pada rancangan pelaksanaan ini berisi tentang pelaksanaan tindakan yang dampaknya terhadap proses dan hasil pembelajaran yang dikumpulkan dengan alat bantu instrument pengamatan yang dikembangkan.

Evaluasi / observasi dilakukan untuk mengetahui hasil dari pembelajaran. Observasi dilakukan dalam setiap tindakan pada setiap siklus, alat yang digunakan adalah lembar observasi. Adapun yang diobservasi adalah mengenai kemampuan motorik halus dalam kegiatan bermain plastisin oleh anak sebagai hasil dari tindakan yang dilakukan di dalam kelas selama proses pembelajaran berlangsung. Selain itu, guru dapat melaksanakan 
evaluasi hasil belajar pada akhir siklus I dengan memberikan kesempatan anak menjahit pola yang lebih sulit dengan tujuan mengetahui seberapa besar kemampuan motorik halus anak berkembang sesuai dengan materi yang telah diberikan.

Kegiatan Observasi merupakan keberhasilan tindakan pada akhir siklus, jika dalam kegiatan ini hasilnya sebagian anak tidak mengalami peningkatan dalam prestasi kemampuan motorik halus dalam kegiatan menjahit, maka akan disempurnakan pada siklus selanjutnya.

Refleksi dilakukan untuk merenungkan dan mengkaji hasil tindakan pada siklus I tentang perkembangan motorik halus. Hasil renungan dan kajian ini, menjadi acuan untuk dicari dan ditetapkan beberapa alternatif tindakan baru yang diduga lebih efektif untuk meningkatkan perkembangan motorik halus anak kelompok $A_{2}$ di TK Laboratorium Undiksha Singaraja. Alternatif tindakan ini akan ditetapkan menjadi tindakan baru pada rencana tindakan dalam tindakan penelitian kelas siklus II.

Adapun rancangan dapat dilihat pada gambar di bawah ini.

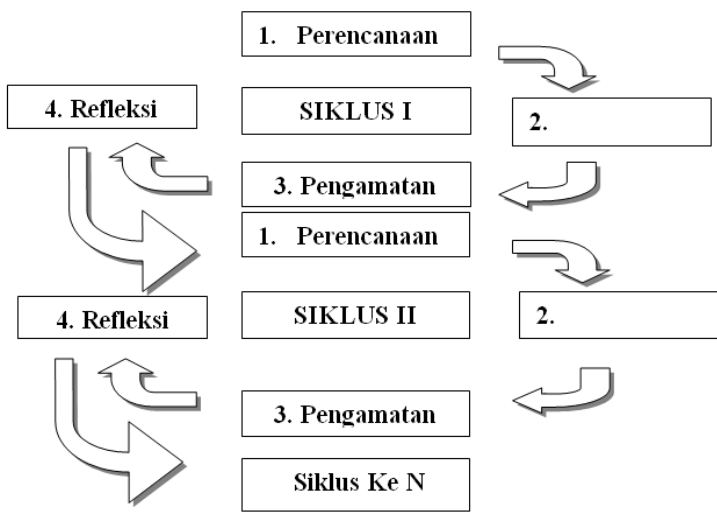

Gambar 3.1 Rancangan Penelitian Tindakan Kelas Model Arikunto, dkk (2009:16)

Untuk mengumpulkan data dalam satuan penelitian, diperlukan suatu metode tertentu untuk memperoleh data yang akurat dan dapat dipertanggungjawabkan. Metode pengumpulan data yang digunakan dalam penelitaian ini adalah metode observasi yang terpacu kisi-kisi instrument. Instrumen yang digunakan dalam penelitian ini berupa lembar observasi dalam bentuk rubrik penskoran. Observasi merupakan pengamatan yang dilakukan secara langsung dan alamiah untuk mengetahui sejauh mana kemampuan motorik halus anak dalam kegiatan menjahit. Pedoman Observasi disusun untuk memudahkan dalam melakukan pengamatan terhadap proses pembelajaran menggunakan media gambar.

Observasi adalah sistem atau rencana untuk mengamati perilaku. Selain itu, observasi juga diartikan sebagai pengamatan dan pencatatan secara sistematik terhadap gejala yang tampak pada objek penelitian menurut Margoni (Setiawan dkk, 2012: 5). Pengamatan dan pencatatan yang dilakukan terhadap objek ditempat terjadi atau berlangsungnya peristiwa sehinggan observe (pengamat) berada bersama objek yang diselidiki disebut observasi langsung. Sedangkan observasi tak langsung adalah pengamatan pencatatan yang dilakukan tidak pada peristiwa tersebut berlangung. Misalnya: melalui film, slide atau foto.

Untuk lebih jelasnya metode dan instrument pengumpulan data dapat dilihat pada tabel di bawah ini. 
Tabel 1 Tabel Kisi-kisi Instrumen Perkembangan Motorik Halus

\begin{tabular}{lc}
\hline \multicolumn{1}{c}{ Kompetensi Dasar } & \multicolumn{1}{c}{ Indikator } \\
\hline 3.3-4.3 Menggunakan anggota tubuh & 1. Memegang dan meremas benda dengan \\
untuk pengembangan motorik kasar & 10 jari \\
dan halus & 2. Membuat bentuk bulatan seperti \\
& kelereng \\
& $\begin{array}{l}\text { 3. Membuat bentuk pipihan seperti sayap } \\
\text { 4. Membuat bentuk segitiga seperti badan } \\
\text { ikan }\end{array}$
\end{tabular}

(Diadaptasi dari kurikulum 2013)

Dari penelitian tersebut sudah terkumpulah data-data yang akan dilanjutkan dengan teknik analisis yaitu dengan menggunakan analisis statistik deskriptif dan metode analisis deskriptif kuantitatif. Menurut Agung (2012:67) bahwa "Metode analisis statistik deskriptif adalah suatu cara pengolahan data yang dilakukan dengan jalan menerapkan rumus-rumus statistik deskriptif seperti, distribusi frekuensi, grafik, angka rata-rata, median, modus, dan standar deviasi untuk menggambarkan suatu objek/variabel tertentu, sehingga diperoleh kesimpulan umum".

Sedangkan metode deskriptif kuantitatif menurut Agung (2012:67) adalah suatu cara pengolahan data yang dilakukan dengan jalan menyusun secara sistematis dalam bentuk angka-angka dan atau presentase mengenai suatu objek yang diteliti sehingga diperoleh kesimpulan umum.

Metode analisis deskriptif kuantitatif ini digunakan untuk menentukan kriteria kemampuan motorik halus yang dikonversikan ke dalam penilaian acuan patokan (PAP) skala lima dan adapun rumus yang digunakan untuk analisis dalam menentukan rata-rata persentase yaitu M\%. Standar PAP skala liama kemampuan motorik halus dalam menulis diuraikan sebagai berikut: a)tingkat penguasaan motorik halus melalui kegiatan menjahit $0 \%$ $54 \%$ masuk dalam kriteria sangat rendah, b)tingkat penguasaan motorik halus melalui kegiatan menjahit 55\%-64\% masuk dalam criteria rendah, c)tingkat penguasaan motorik halus melalui kegiatan menjahit 65\%-79\% masuk dalam kriteria sedang, d) tingkat penguasaan motorik halus melalui kegiatan menjahit $80 \%-89 \%$ masuk dalam kriteria tinggi, dan e) tingkat penguasaan motorik halus melalui kegiatan menjahit 90\%-100\% masuk dalam kriterian tinggi.

Sebagai suatu tolak ukur dalam penelitian ini akan ditetapkan indikator keberhasilan. Adapun indikator keberhasilan tersebut adalah sebagai berikut (1)Terjadinya peningkatan perkembangan motorik halus sampai mencapai katagori tinggi (80-89\%). (2) Secara klasikal perkembangan motorik halus anak berkembang sesuai harapan mencapai $80 \%$ dari jumlah 18 anak.

\section{HASIL DAN PEMBAHASAN}

Penelitian tindakan kelas ini dilaksanakan pada anak kelompok $A_{2}$ TK Laboratorium Undiksha Singaraja Tahun Pelajaran 2018/2019 dengan jumlah subjek sebanyak 18 anak yang terdiri dari 9 orang anak perempuan dan 9 orang anak laki-laki. Penelitian ini dilaksanakan dalam II siklus. Tema yang digunakan pada saat penelitian ini berlangsung, mengikuti tema yang diterapkan oleh sekolah yaitu tema binatang. Data yang dikumpulkan adalah data tentang perkembangan motorik halus melalui bermain plastisin. Data tersebut 
dianalisis dengan menggunakan metode analisis statistik deskriptif dan metode analisis deskriptif kuantitatif. Kegiatan penelitian ini dilaksanakan pada bulan September - Oktober 2018. Hasil penelitian tersebut dapat dipaparkan sebagai berikut.

Siklus I dilaksanaan 4x pertemua yaitu 4 kali pertemuan untuk pelaksanaan tindakan dan untuk evaluasi penilaian setelah melakukan pembelajaran terhadap kemampuan motorik halus pada anak kelompok $\mathrm{A}_{2}$ yang berjumlah 18 anak. Pelaksanaan tindakan pada siklus I dilaksanakan berdasarkan Rencana Pembelajaran Harian (RPPH) yang sudah disiapkan sebelumnya.

Data perkembangan motorik halus dalam kegiatan bermain plastisin tersebut disajikan dalam bentuk tabel distribusi frekuensi, menghitung modus (Mo), median (Me), mean (M) dan membandingkan

rata-

rata atau mean dengan model PAP skala lima. Dari hasil evaluasi yang telah dilaksanakan diperoleh data berupa skor sebagai berikut. Penyajian data kedalam table distribusi frekuensi ditempuh beberapa langkah seperti menghintung rentangan, menghitung banyak kelas interval, menghitung panjang kelas interval. Dari data tersebut maka diperoleh data sebagai berikut.

Tabel 1 : Distribusi Frekuensi Data Skor Kemampuan Motorik halus melalui bermain plastisin Kelompok A2 Semester I Tahun Pelajaran 2018/2019 di TK Laboratorium Undiksha pada Siklus I

\begin{tabular}{|c|c|c|c|}
\hline $\begin{array}{c}\text { Skor } \\
(\mathbf{X})\end{array}$ & $\mathbf{F}$ & $\mathbf{F k}$ & $\mathbf{F x}$ \\
\hline 12 & 2 & 18 & 24 \\
\hline 11 & 2 & 16 & 22 \\
\hline 10 & 5 & 14 & 50 \\
\hline 9 & 1 & 9 & 9 \\
\hline 8 & 6 & 8 & 48 \\
\hline 7 & 1 & 2 & 6 \\
\hline 6 & 1 & 1 & $\mathbf{1 6 6}$ \\
\hline Total & $\mathbf{1 8}$ & & $(\mathbf{\Sigma})$ \\
\hline
\end{tabular}

Maka dari tabel distribusi tersebut didapatkan data kemampuan motorik halus anak melalui kegiatan bermain plastisin nilai ratarata(mean) pada siklus I adalah 9.22 nilai modus pada siklus I adalah 8, dan nilai median pada siklus I adalah 9. Dan dari nilai tersebut maka grafik polygon pada siklus I yaitu sebagai berikut.

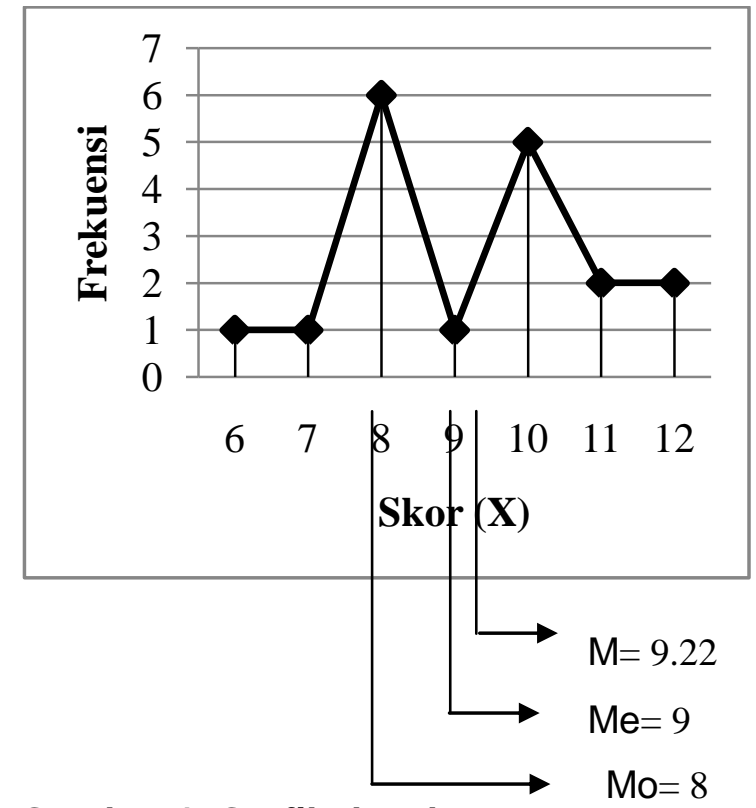

Gambar 1. Grafik data kemampuan motorik halus melalui bermain plastisin pada siklus I 
Berdasarkan perhitungan dan grafik polygon di atas, terlihat $\mathrm{Mo}<\mathrm{Me}<\mathrm{M}(8<9<9.22)$, sehingga dapat disimpulkan bahwa sebaran data kemampuan motorik halus melalui bermain plastisin pada siklus I menunjukkan kurve juling positif. Dengan demikian dapat di interpretasikan bahwa skor kemampuan motorik halus anak pada siklus I cenderung rendah.

Melalui perbaikan proses pembelajaran dan pelaksanaan tindakan pada siklus I, maka nampak terjadi peningkatan proses pembelajaran siklus II. Siklus II dilaksanakan 4 kali pertemuan yaitu 4 kali pertemuan tindakan dan untuk evaluasi penilaian setelah melakukan pembelajaran terhadap kemampuan motorik halus melalui bermain plastisin pada anak kelompok $A_{2}$ yang berjumlah 18 orang. Pelaksanaan tindakan pada siklus II dilaksanakan berdasarkan RPPH (Rencana Pelaksanaan Pembelajaran Harian) yang sudah disiapkan sebelumnya.

Data kemampuan motorik halus melalui bermain plastisin disajikan dalam bentuk tabel distribusi frekuensi, menghitung modus (Mo), median (Me), mean (M) dan membandingkan rata-rata atau mean dengan model PAP skala lima. Adapun data pada siklus II sebagai berikut :

Tabel 2 : Distribusi Frekuensi Data Skor Kemampuan Motorik halus melalui bermain plastisin Kelompok A2 Semester I Tahun Pelajaran 2018/2019 di TK Laboratorium Undiksha pada Siklus II

\begin{tabular}{|c|c|c|c|}
\hline $\begin{array}{c}\text { Skor } \\
(\mathbf{X})\end{array}$ & F & Fk & Fx \\
\hline 15 & 2 & 18 & 30 \\
\hline 14 & 7 & 16 & 98 \\
\hline 13 & 3 & 9 & 65 \\
\hline 12 & 2 & 6 & 12 \\
\hline 11 & 1 & 4 & 11 \\
\hline 10 & 1 & 3 & 10 \\
\hline 9 & 2 & 2 & 9 \\
\hline Total & 18 & & 235 \\
& $(\mathrm{~N})$ & & $(\mathrm{ZfX})$ \\
\hline
\end{tabular}

Proses penivelajalalı uapal verjalalı sesual uerıyalı rencana pelaksanaan pembelajaran yang direncanakan oleh peneliti, sehingga kemampuan motorik halus anak dapat meningkat. Peningkatan kemampuan motorik halus anak dapat dilihat melalui grafik berikut.

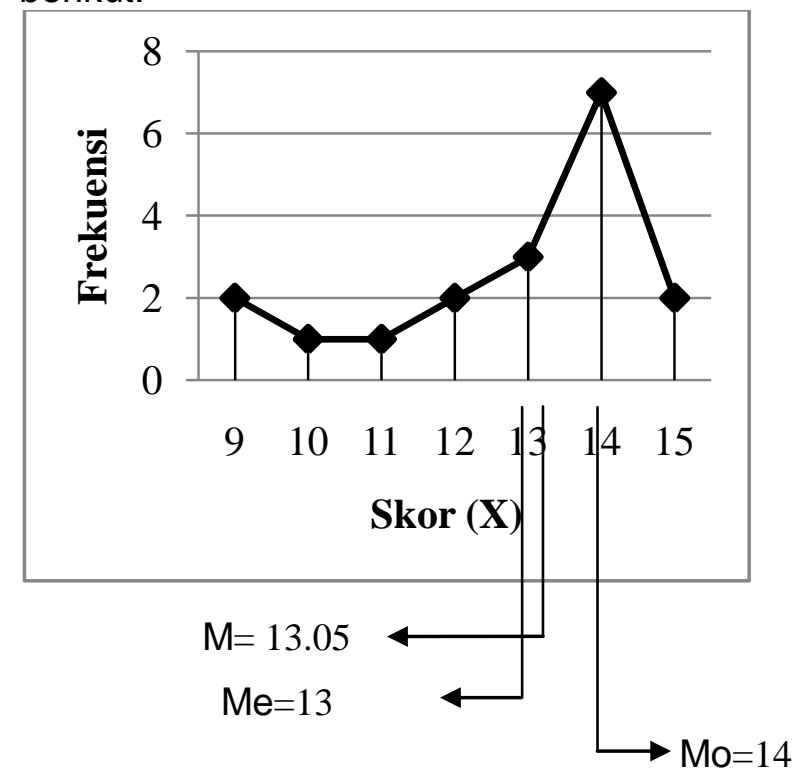

Gambar 2 Grafik Data Kemampuan Motorik Halus Melalui Bermain Plastisin pada Siklus II 
$14>13>13,05)$, sehingga dapat disimpulkan bahwa sebaran data kemampuan motorik halus melalui bermain plastisin pada siklus II menunjukkan kurve juling positif. Dengan demikian dapat di interpretasikan bahwa skor kemampuan motorik halus anak pada siklus II merada pada kategori tinggi.

Setelah dilaksanakan perbaikan dari proses pembelajaran siklus I, dalam pelaksanaan siklus II terjadi peningkatan yang dapat dilihat pada kemampuan motorik halus melalui bermain plastisin yang sebelumnya berada pada kriteria rendah meningkat menjadi kriteria tinggi.

Secara umum proses pembelajaran melalui bermain plastisin untuk meningkatkan kemampuan motorik halus pada anak kelompok A2 berlangsung sesuai dengan perencanaan dan telah mencapai indikator keberhasilan. Hal ini terlihat dari adanya peningkatan rata-rata persentase dari sikus I sebesar $56,61 \%$ ke siklus II sebesar $80,12 \%$, sehingga penelitian ini tidak dilanjutkan ke siklus berikutnya.

Berdasarkan hasil analisis data penelitian yang telah dilaksanakan dalam dua siklus menunjukkan terjadinya peningkatan kemampuan motorik halus melalui bermain plastisin pada anak kelompok $A_{2}$ TK Laboratorium Undiksha Singaraja. Setelah dilaksanakan tindakan pada siklus I diperoleh rata-rata persentase yaitu $57,62 \%$ pada kategori rendah menjadi $81,56 \%$ pada siklus II dengan kategori tinggi. Hal ini menunjukkan adanya peningkatan rata-rata persentase perkembangan motorik halus anak dalam bermain plastisin dari siklus I ke siklus II mencapai 22, 94\%.

Peningkatan ini dikarenakan penerapan bermain plastisin sehingga terjadi peningkatan kemampuan motorik halus. Hasil ini didukung oleh pendapat Piaget (dalam Sujiono, 2013: 144) mengatakan bahwa bermain adalah suatu kegiatan yang dilakukan berulang-ulang dan menimbulkan kesenangan atau kepuasan bagi diri seseorang, sedangkan Parten (dalam Dockett dan Fleer, 2000: 14) memandang kegiatan bermain sebagai sarana sosialisasi, diharapkan melalui bermain dapat memberi kesempatan anak bereksplorasi, menemukan, mengekspresikan perasaan, berkreasi, dan belajar secara menyenangkan. Selain itu, kegiatan bermain dapat membantu anak mengenal tentang diri sendiri, dengan siapa anak hidup serta lingkungan tempat dimana anak hidup.

Guru TK sering kali kurang menyadari bahwa bermain plastisin dapat mengkoordinasikan jari-jari tangan, melenturkan otot-otot jari tangan, melatih keuletan dan kesabaran serta mengembangkan imajinasi dan kreativitas anak. Oleh karena itu, bermain plastisin merupakan langkah yang baik untuk meningkatkan kemampuan motorik halus anak. Jari-jari anak semakin kuat apabila sering diterapkan kegiatan bermain plastisin ini, sehingga dapat memegang pensil dengan sempurna, mengancingkan baju, menggunting, memegang kuas dan sebagainya. Hasil bermain plastisin yang diberikan secara tepat menjadi kemampuan prasyarat anak untuk memperoleh pengalaman belajar yang lebih luas, tinggi dan komplek.

Berdasarkan hasil penelitian dan uraian tersebut dapat disimpulkan bahwa melalui penerapan belajar melalui bermain plastisin dapat meningkatkan kemampuan motorik halus pada anak kelompok $\mathrm{A}_{2}$ semester I di TK Laboratorium Undiksha yang mendapat peningkatan sebesar $22,94 \%$.

\section{SIMPULAN DAN SARAN}

Berdasarkan pembahasan dan analisis yang telah dilakukan serta dari hasil kegiatan pengajaran yang dilakukan selama dua siklus dapat disimpulkan bahwa terdapat peningkatan kemampuan motorik halus pada anak kelompok $A_{2}$ di TK Laboratorium Undiksha Singaraja setelah diterapkan melalui bermain plastisin mengalami peningkatan mencapai $22,94 \%$. Persentase rata-rata kemampuan motorik halus pada siklus I, M\%=57, $62 \%$ yang berada pada kategori rendah menjadi sebesar $81,56 \%$ pada siklus II yang berada pada kategori tinggi. Dengan demikian dapat disimpulkan bahwa dengan bermain plastisin dapat meningkatkan kemampuan motorik halus anak kelompok $\mathrm{A}_{2}$ di TK Laboratorium Undiksha Tahun Pelajaran 2018/2019. 
Saran yang diberikan yaitu perlunya alat bermain atau media yang benar-benar efektif seperti plastisin, playdough ataupun alat peraga lainnya yang bervariasi dalam pengajaran untuk meningkatkan kemampuan motorik halus anak, menciptakan suasana belajar yang menyenangkan melalui permainan-permainan yang bervariasi seperti bermain plastisin, serta memberikan stimulus seperti motivasi sehingga anak lebih berani dan antusias untuk mengikuti kegiatan pembelajaran, dan sebaiknya guru dalam menyampaikan materi perlu mempersiapkan secara bertahap, berurutan dan pengucapan yang jelas serta menenangkan anak dan membuat aturan main sebelum memulai kegiatan.

\section{DAFTAR PUSTAKA}

Agung, A. A. Gede. 2010. Penelitian Tindakan Kelas Teori dan Analisis Data dalam PTK. Singaraja: Universitas Pendidikan Ganesha.

A. A. Gede. 2012. Metodologi Penelitian Pendidikan. Singaraja. Universitas Pendidikan Ganesha.

Arikunto, Suharsimi, dkk. (2008). Penelitian Tindakan Kelas. Jakarta: Bumi Aksara.

Peraturan Menteri Pendidikan dan Kebudayaan Nomor 137 Tahun 2014 tentang Standar Nasional Pendidikan anak Usia DiniMontolalu, B.E.F, dkk. (2009). Bermaindan Permainan Anak. Jakarta: Universitas Terbuka

Septiari Bea Bety. 2012. Mencetak Balita Cerdas dan Pola Asuh Orang Tua. Yogyakarta: Nuha Medika.

Suyadi. 2009. Buku Pegangan Bimbingan Konseling untuk PAUD. Jogjakarta: Diva Press

Well Mina.Membuat Plastisin yang Menyenangkan Sejarah Clay. Tersedia di http://www.scribd.com/dok/80089975/plastisin diakses tanggal 10 Oktober 2018 